by European Commission President Barroso, "Europe's economic future depends on having the most highly educated and trained people, with the full range of skills and the adaptability required in a 'knowledge economy.' That is why we must boost investment in higher education significantly. The commission is suggesting a target [investment for higher education] of 2 percent of gross domestic product by $2010 . "$

\section{Public Money for Private Higher Education}

\section{Daniel C. Levy}

Daniel Levy is director of the Program for Research on Private Higher Education (PROPHE) and is a SUNY Distinguished Professor. Address: ED321, University at Albany, Albany, NY 12222, USA. E-mail: dlevy@albany.edu.

IHE devotes a column in each issue to a contribution from PROPHE, the Program for Research on Private Higher Education, headquartered at the University at Albany. See http://www.albany.edu/dept/eaps/prophe/.

$\mathrm{P}$ ublic money for private higher education is a major policy issue for governments, the general public, and of course private institutions-all the more so as the private sector has risen to roughly 30 percent of total global enrollment and is continuing to grow. Yet, a key baseline is the fact that public funding of private higher education is the exception, not the rule. This reality is often obscured by contrary examples that lead to the absurd notion that source of income does not seriously distinguish the two sectors of higher education. In fact, just as public higher education is overwhelmingly sustained by public money, private higher education is just as overwhelmingly sustained by private money. This generalization is particularly strong in the developing world and the postcommunist world-the two greatest sites of private higher education expansion. Nonetheless, examples of public money for private higher education are significant and increasing.

\section{Full-Blown National Cases}

Probably the most-cited cases where private higher education depends on public funding, to almost the same extent as public higher education does, are found in Belgium and the Netherlands. The roots lie early in the last century, with the idea that religious and cultural groups could have their own private universities, and since all groups hold that same right the public would legitimately fund all institutions. This is essentially a voucher principle. Though not as much in governance as in finance, private universities would resemble public ones except for the one area of cultural distinctiveness.

Chile by midcentury came to provide a clear developing country case of public funding of the private sector. Alongside the two public universities, all six private ones (both religious and secular) became basically publicly funded. A startling change then ensued under military neoliberal rule in the I980s: the proliferation of truly private universities. These constitute the "private sector," whereas the six prior institutions are labelled "old privates."

With independence, India saw a massive shift in funding and governance. An enormous network of private colleges, affiliated to universities, became essentially public. Here, too, however, a fresh wave of private proliferation has exploded onto the scene, accounting now for perhaps 30 percent of total enrollments.

Other cases of public takeover were even more extreme but concerned abolition of private higher education, not just public funding of still formally private institutions. In the I970s Turkey was one example and the communist bloc the major set of examples.

\section{RATIONALES}

Justifications for public funding are multiple, as are arguments against that policy. One rational is fair and equal treatment of students, regardless of their institutions. Another is access, particularly if the private sector offers slots beyond what the

Probably the most-cited cases where private higher education depends on public funding, to almost the same extent as public higher education does, are found in Belgium and the Netherlands.

public sector provides yet needs certain cost-sharing. The access rationale strengthens in areas where the populations are less privileged. More broadly, in public-private partnerships the public side pursues public goals, with public money, but entrusts management largely to private nonprofit organizations. Sometimes this policy involves direct contracting out for a specific public end but often just general ongoing grants.

Other major rationales involve quality and incentives. Where this orientation is found the whole private sector does not qualify for funding; instead, public money is dispersed according to sets of criteria. Funding is thus "sector blind," which hardly insures equal amounts to the two sectors. Indeed, most private institutions and units within favored institutions may not receive such money. Public money may motivate private institutions to improve (e.g., seek accreditation) or expand; in turn, governments may relish forcing public universities to compete for some of their funding. Often, private institutions continue to carry out their most basic goals 
supported by private money but go further when they can add public money. Research and graduate education are examples.

In much of Asia, decades of reliance on private higher education for the bulk of enrollments supported access but left concern over quality and breadth, providing a strong rationale for public funding to enable the private sector to reach the next level. In the Middle East, a number of governments have joined local private (and sometimes international) actors to launch a private sector, even if no plans exist for permanent public funding. An overlapping rationale can be to provide higher education opportunity so as to limit high rates of studying abroad.

\section{The US MOdeLs}

Most of these rationales have long affected the US system. The US case constitutes the largest fountain of ideas and precedents. Two types of funding dominate at the national level, though often with a strong echo at state levels.

First, regarding research, almost wherever major costly research has been carried out at private universities, public funding has been essential. Leading US private research universities often outdraw public university counterparts in winning federal research funding. In Latin America, Brazil and Chile represent the foremost examples of open competition for public research funds. Similarly, they and other countries in the region have rewards for productive professors regardless of whether they are at public or private institutions.

The other major type of US public funding subsidizing private higher education is student grants and loans.

Second, regarding students, the other major type of US public funding subsidizing private higher education is student grants and loans. Students are eligible as long as their institutions are accredited; this funding applies even to for-profit institutions. The grants and loans are usually needs-based and go hand-in-hand with access and efficiency rationales. The idea inspires international applause (at least where not extended to for-profit institutions). While still a limited reality, such forms of student funding could be introduced if feasible domestic modalities for loan repayments are found. Thailand is an example of where income-contingent loans have recently been established (along with grants-in-aid) for private higher education.

It is unknown how far public funding of private higher education will extend internationally or in what forms. Some of the pertinent policy issues show parallels at the primary and secondary education levels. Public funding of private higher education remains unusual internationally, but changes in public policy may occur.

\section{Private Deemed Universities in India}

\section{PAWAN AGarwal}

Pawan Agarwal is secretary of the Department of Science and Technology, Government of West Bengal, India. E-mail: pawan.agarwalo6@ gmail.com.

Though the third-largest system in terms of enrollment, 1 with more than Io million students, India has almost half of the world's institutions of higher education-almost four times more than in the United States and Europe and over seven times the number of institutions in China. Most of the I8,000 institutions in India are colleges and only around 370 are universities. While universities award their own degrees, the colleges award degrees through the university to which they are affiliated. Only I 20 of the 370 universities are the affiliating type, the rest are unitary with no affiliated colleges. Academic degrees in India can only be awarded by a university. Both the national Parliament and the state legislatures can authorize the establishment of universities. In addition, the national government can grant "deemed university" status to an institution initially founded as a private or public college.

The distinction between a private and public institution in Indian higher education is somewhat blurred. If the government promotes and sets up an institution, it is referred to as a public institution. On the other hand, an institution promoted and set up by a private promoter is referred to as a private institution. However, some private institutions (both universities and colleges) are government supported and highly regulated. Though technically private, these are de facto public institutions. Hence, private institutions here include only institutions that are set up by private promoters and do not receive government funding.

\section{Private Growth}

Over the past 20 years, the higher education capacity in the country has increased largely through private institutions. Currently, 43 percent of institutions and 30 percent of enrollments are in the private sector. Among the countries for which information has been gathered by the Program for Research on Private Higher Education (PROPHE), India's level of private enrollments exceeds 35 countries and trails just I2.

Until recently, these private institutions consisted mostly of colleges. These private colleges are subject to government control via the public universities with which they are affiliated. They lack the autonomy to offer new programs, innovate curricula and evaluation, or change policies in matters of admissions and fees. Many people believe that the affiliating structure is a bane on Indian higher education. However, the affili- 